\title{
Characterization and Biological Activity Test of Garlic and Its Fermentation as Antioxidant, Analgesic, and Anticancer
}

\author{
Sri Atun"1, Nurfina Aznam ${ }^{1}$, Retno Arianingrum ${ }^{1}$, Senam ${ }^{1}$, Yashinta Devi ${ }^{1}$, Riski \\ Melasari $^{1}$
}

${ }^{1}$ Departement of Chemistry education, Faculty Mathematic and line Natural Science, Universitas Negeri Yogyakarta, Indonesia, Jl. Colombo No. 1 Depok, Sleman, Yogyakarta, Indonesia, 55281

${ }^{*}$ Corresponding author: sriatun@uny.ac.id

\begin{abstract}
The purpose of this study was to characterize and biological activity test of garlic and its fermented products (black garlic) as antioxidants, analgesics, and anticancer properties. The subject of this study was garlic and its fermented products (black garlic). Characterization includes analysis of total phenol content, flavonoid content, and identification of isolated components by FT-IR and GC-MS. The analysis of total phenolic and flavonoid content was carried out by spectroscopic methods. The antioxidant activity test used the DPPH (2,2-diphenylpicrylhydrazyl) method. The analgesic test used the mouse stretching method induced by acetic acid. Anticancer tests are carried out through cytotoxicity tests on several cancer cell lines. The cytotoxicity test method was carried out with the MTT Cell Proliferation Kit using a colorimetric method. The results showed that the garlic and black garlic extracts had high phenolic and flavonoid content. Chromatographic separation of ethyl acetate extract from black garlic obtained compound A with a purity of $67.69 \%$. The results of the identification of compound A using IR and GC-MS showed that the isolated compound had similarities with 5-hydroxymethylfurfural. The antioxidant activity test of each extract and fraction of garlic and black garlic was classified as low, except for the ethanol extract of black garlic which showed high antioxidant activity with $\mathrm{IC}_{50} 38.609 \pm 0.11 \mu \mathrm{g} / \mathrm{mL}$. The ethanol extracts of garlic and black garlic showed analgesic activity but showed low toxicity in several types of cancer cells T47D, 4T1, MCF7 / Her2, HeLa, and WiDr.
\end{abstract}

Keywords: Allium sativum, antioxidant, analgesic, anticancer, Garlic, fermented garlic, black garlic, phenolic.

\section{INTRODUCTION}

The garlic plant has been cultivated since ancient Egypt, used as a spice and flavoring, and has medicinal potential, so it is widely used in the cultures of various nations. The health benefits of the chemical component garlic in treating various disorders have been studied in both animals and humans [1]. Several studies have shown that garlic and its fermented (black garlic) have antioxidants $[2 ; 3 ; 4 ; 5 ; 6]$, anti-genotoxic [5], antiinflammatory [6], anti-leukemic [7], and anti-allergic [8]. Single garlic or with the local name "bawang lanang" is included in the Alliaceae family of the genus Allium, with the species Allium sativum L. Single garlic or with the local name "bawang lanang" is included in the Alliaceae family of the genus Allium, with the species Allium sativum L. Today the use of garlic for health has developed in various product forms.
The black garlic produced from fresh garlic which is fermented for some time at a controlled temperature (60-90) ${ }^{\circ} \mathrm{C}$ under high humidity (80-90) \% [9]. When compared to fresh garlic, black garlic does not give off a strong taste because of the reduced allicin content, and unlike regular garlic, this black garlic has a soft, chewy, savory texture and a slightly sweet taste. Figure 1 shows the image of garlic and black garlic. The increased bioactivity of black garlic compared to fresh garlic was associated with changes in physicochemical properties. Several studies showed differences in the composition and activity properties of fermented garlic (black garlic) and garlic [10]. This study aims to characterize and test the biological activity of garlic and its fermented products (black garlic) as antioxidants, analgesics, and anticancer.

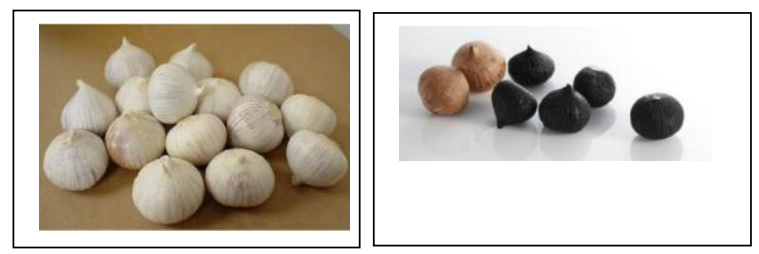


Figure 1.Garlic ("bawang lanang") and its fermented (black garlic)

\section{EXPERIMENTAL SECTION}

\subsection{Apparatus and reagent}

In this study used various equipment including evaporator Buchi Rotavapor R-215, FTIR Shimadzu Prestige 21, GCMS QP 2010S Shimadzu, 722N Visible Spectrophotometer, vortex mixer, column chromatography, TLC chamber, tissue culture flask, 96 microtiter plates well, and glassware. Materials used include organic solvents such as ethanol, methanol, $n$ hexane, ethyl acetate, folin-ciocalteu reagents, sodium carbonate, gallic acid (Sigma), rutine (Sigma), aluminum nitrate, potassium acetate, white garlic, black garlic, 2,2-diphenyl-1-picrilhidrazil (DPPH, Aldrich), ascorbic acid (Aldrich), aquadest, T47D, 4T1, MCF7 / Her2; HeLa; and WiDr cell lines, some reagents such as washing solutions (99\% RPMI (Gibco), 1\% repellent, (Gibco); storage media $-70{ }^{\circ} \mathrm{C}$ (20\% FBS (Gibco), $70 \%$ RPMI requiring $1 \%$ repellent and $1 \%$ fungizon, $10 \%$ DMSO); culture media (89\% RPMI, $1 \%$ sprayer, $10 \%$ FBS); nitrocellulose filter paper $0.22 \mu \mathrm{m}$ (Whatman)); the blue dye tripan (Sigma); MTT solution (3- (4,5dimethyltiazol-2-il) -2,5-diphenyltetrazolium bromide dissolved in PBS at a concentration of $5 \mathrm{mg} / \mathrm{ml}$; formazan solvent (10\% SDS in $0.01 \mathrm{~N}$ hydrochloric acid), acetic acid, acetosal, carboxyl methyl celulose (CMC).

\subsection{Procedures for extracting, isolating, and identifying components from garlic}

Each garlic and black garlic are mashed to form a powder. A total of $1 \mathrm{~kg}$ of each garlic and black garlic was then macerated with ethanol for 24 hours at room temperature while stirring occasionally. The filtrate was separated and the residue was macerated again 3 times. The filtrate obtained was collected and concentrated using a vacuum evaporator, so that a thick ethanol extract was obtained. The ethanol extract obtained was then fractionated with n-hexane, chloroform, and ethyl acetate. Each extract from the fractionation results is then concentrated by vacuum, and used for further tests. Data from the extraction and partition results of each type of garlic are listed in Table 1. This study also extracted water from each type of garlic. Water extract is made by adding $500 \mathrm{ml}$ of distilled water to $100 \mathrm{~g}$ of garlic sample then heated for 30 minutes. The mixture is then separated by filtering. The filtrate obtained is then used for research. Chromatographic separation of components was only carried out on the ethyl acetate fraction of black garlic that showed component A having a purity of $67.89 \%$. Component identification was carried out by IR and GC-MS.

\subsection{Determination of total phenolic and flavanoid content}

The determination of total phenolic content was carried out using the Folin-Ciocalteau reagent [11]. A total of $1 \mathrm{ml}$ of $15 \% \mathrm{Na} 2 \mathrm{CO} 3$ solution and $2 \mathrm{ml}$ of distilled water were added to the test tube containing the $0.5 \mathrm{ml}(1000 \mu \mathrm{g} / \mathrm{ml})$ sample solution. The solution was incubated for 10 minutes at $500 \mathrm{C}$. The solution was then homogenized using a vortex mixer and let stand for 1 hour. The absorption of each solution was measured using a Visible Spectrophotometer at a wavelength of $760 \mathrm{~nm}$. Gallic acid is used as a standard made at various concentrations. Total phenolic content is defined as milligrams of gallic acid per gram of extract. Each sample was repeated three times.

The determination of total flavonoid levels in each extract and fraction of white garlic and black garlic was carried out by the spectrophotometric method by adding $\mathrm{AlNO}_{3}$ and $\mathrm{CH}_{3} \mathrm{COOK}$ solutions [12]. A total of $0.5 \mathrm{ml}$ of $10 \% \mathrm{AlNO}_{3}$ solution, $0.1 \mathrm{ml}$ of $\mathrm{CH}_{3} \mathrm{COOK} 1 \mathrm{M}$ solution, and $4.3 \mathrm{ml}$ of distilled water were added to the test tube containing $0.5 \mathrm{ml}$ of sample solution (10.000 $\mu \mathrm{g} / \mathrm{ml})$. Each solution was repeated three times, then homogenized and allowed to stand for 40 minutes at room temperature. The absorbance of each sample solution was measured using a Visible Spectrophotometer at a wavelength of $416 \mathrm{~nm}$. As a standard solution, rutine compounds are used at various concentrations. Total flavonoid levels were interpreted as rutine equivalent milligrams per gram of extract mass.

\subsection{Antioxidant activity test}

The antioxidant activity test was carried out by the DPPH method, namely using 2,2-diphenyl-1picrylhydracil (DPPH) as a source of radicals [13]. The sample was dissolved in ethanol at various concentrations. The sample solution was reacted with DPPH solution (with a ratio of 1: 1). The solution was then placed in a dark room at room temperature for 30 minutes. The absorption of each solution was measured using visible spectroscopy at a wavelength of $516 \mathrm{~nm}$ and compared with the absorbance of the control solution. The antioxidant activity of each sample is calculated using the following formula:

\section{$\%$ Antioxidant activity = [A Control - A sample] x 100\% [ A Control]}

The $\mathrm{IC}_{50}$ value of each sample was calculated using a regression equation of the percentage of antioxidant activity at various concentrations. As a positive control, ascorbic acid was used. 


\subsection{Analgesic test}

The analgesic test used the writhing method in mice [14]. Induction in male mice was done intraperitoneally by injecting acetic acid. Pain in male mice is indicated by stretching namely, the stomach (abdomen) touches the base where the male mice are placed and the male mice's legs are fully pulled back. Mice were divided into eight groups, each using 5 male mice. In group 1 (positive control), each mice was given acetosal orally and then induced with acetic acid. In group 2 (negative control), each mice was given CMC $0.5 \%$ orally then induced with acetic acid. In groups 3,4 and 5 each mice was given white garlic ethanol extract sequentially at a dose of $100 ; 200 ; 400 \mathrm{mg} / \mathrm{kg} \mathrm{BW}$, then induced with acetic acid. In groups 6,7,8, each mouse was given ethanol extract of black garlic sequentially, each with a dose of $100 ; 200 ; 400 \mathrm{mg} / \mathrm{kg}$ BW respectively. After 5 minutes of treatment, the number of stretches of each mice was counted every five minutes continuously for one hour. The percentage of protection against acetic acid induction with the formula:

$\%$ Protection $=\frac{\mathrm{AWC}-\mathrm{AWE}}{\mathrm{AWC}} \times 100 \%$

AWC $=$ The average number of writhing mice in negative control group

$\mathrm{AWE}=$ The average number of writhing mice in experiment group

\subsection{Cytotoxicity activity test against cancer cells}

The in vitro cytotoxicity test was investigated using 96 wells plate [15]. The sample is dissolved in a suitable phosphate buffer or solvent. Each well was put in $100 \mu \mathrm{l}$ of RPMI media containing 4\% penstrep, $100 \mu \mathrm{l}$ of samples at various concentrations of $25 \mu \mathrm{g}$ to $0.05 \mu \mathrm{g}$, then added $100 \mu \mathrm{l}$ of cancer cells (Cancer cell lines used in this research: T47D, 4T1; MCF7 / Her2; HeLa; and WiDr) in culture media with the number of cells 5 x 104 each well. As a blank, $100 \mu \mathrm{l}$ of potassium phosphate buffer $\mathrm{pH} 7.2$ was used as a series dilution, and two replications were performed for each sample. At the end of the incubation, $10 \mu \mathrm{l}$ of MTT $(50 \mu \mathrm{g} / \mathrm{ml})$ was added to each well, then incubated again for 4 hours. Living cells will react with MTT to form formazan which gives a purple color. The reaction was stopped by adding 100 $\mu \mathrm{l}$ SDS $10 \%$ in $\mathrm{HCl} 0.01 \mathrm{~N}$, then incubated at room temperature overnight then read with a Benchmark microplate reader at a wavelength of $595 \mathrm{~nm}$. Cell viability was calculated by the formula:

$\%$ of living cells $=($ abs $\mathrm{P}-$ abs $\mathrm{M}) /($ abs $\mathrm{K}-\mathrm{abs} \mathrm{M}) \mathrm{x}$ $100 \%$

abs $\mathrm{P}=$ absorbance of cells treated; abs $\mathrm{M}=$ absorbance of the media

abs $\mathrm{K}=$ absorbance of control cells

The $\mathrm{IC}_{50}$ value is determined by probit analysis in the SPSS 11.5 program

\section{RESULTS AND DISCUSSION}

The garlic used in this study is local garlic obtained from farmers in the Wonosobo area of Central Java. Partially fermented garlic at $70^{\circ} \mathrm{C}$ using magic com for two weeks to form black garlic. The sample in this study used $1 \mathrm{~kg}$ of garlic and $1 \mathrm{~kg}$ of black garlic. The two samples of each garlic are then peeled and blended until smooth. Each sample was then macerated using ethanol as a solvent. The maceration method is carried out by immersing the sample in ethanol solvent for 24 hours while stirring occasionally. Ethanol solvent was chosen because it can extract the desired substance, ethanol also has a low boiling point and can dissolve almost all secondary metabolites. Soaking is done three times. Each ethanol extract obtained was then concentrated using a Buchi R-215 rotary evaporator to obtain concentrated ethanol extract. Each extract was then partitioned successively using $n$-hexane, chloroform, and ethyl acetate, to obtain $n$-hexane fraction, chloroform fraction, ethyl acetate fraction, and ethanolsoluble residual fraction. Each fraction is then concentrated to obtain solids. The extract and fraction obtained are then used for further research. Data from the extraction and partition of each sample can be seen in Table 1. In this study, we also made water extracts from each type of garlic. The water extract was prepared by adding $500 \mathrm{ml}$ of distilled water to $100 \mathrm{~g}$ of each sample of garlic and then heating it for 30 minutes. The mixture is then separated by filtering. The filtrate obtained was then used for research.

The determination of the total phenolic content was carried out by the method of adding Folin-Ciocalteau reagent [11]. The absorption of each mixture was measured at a wavelength of $760 \mathrm{~nm}$. As a standard phenolic compound gallic acid was used at various concentrations (50-200 $\mu \mathrm{g} / \mathrm{ml}$ ) and the absorbance was measured at the same wavelength. The measurement results obtained by the calibration curve with the linear regression equation $y=0.0043 x+0.0339\left(R^{2}=0.993\right)$. Total phenolic content is expressed as $\mathrm{mg}$ of Gallic Acid Equivalents (GAE) per $g$ of plant extract. The determination of total flavonoid levels in each extract and fraction of garlic and black onions was carried out by the spectrophotometric method [12]. In this study, to determine the total flavonoid levels, Rutine standard compounds were used at various concentrations (50-200 $\mu \mathrm{g} / \mathrm{ml}$ ) and the absorbance was measured at a wavelength of $415 \mathrm{~nm}$. The measurement results obtained by the regression equation as a calibration curve with a linear regression equation $\mathrm{y}=0.0032 \mathrm{x}+$ $0.0999\left(\mathrm{R}^{2}=0.9631\right)$. The total flavonoid content is expressed as $\mathrm{mg}$ of Rutine Equivalents (RE) per $\mathrm{g}$ of plant extract. The results of the analysis of phenolic and flavonoid levels of each extract and fraction of garlic and black garlic are shown in Table 1. 
Table 1. Extract and fraction result of white garlic and black garlic, total phenolic and flavonoid content

\begin{tabular}{|c|c|c|c|c|}
\hline & Sample & weight (g) & $\begin{array}{l}\text { Phenolic content } \\
\text { (mg galic acid/g }\end{array}$ & $\begin{array}{l}\text { Flavonoid } \\
\text { content (mg }\end{array}$ \\
\hline & Ethanol extract garlic & 300 & $71.54 \pm 11.31$ & $2.32 \pm 0.22$ \\
\hline & $n$-hexana fraction of garlic & 80 & $79.59 \pm 6.64$ & $6.55 \pm 0.75$ \\
\hline A & Chloroform fraction of garlic & 120 & $77.77 \pm 11.57$ & $2.11 \pm 0.87$ \\
\hline & Ethyl acetate fraction of garlic & 0 & Not detected & Not detected \\
\hline & Residu of ethanol fraction of garlic & 95 & $68.56 \pm 5.13$ & $0.23 \pm 0.09$ \\
\hline & Ethanol extract of black garlic & 354 & $306.09 \pm 32.23$ & $9.25 \pm 0.55$ \\
\hline & $n$-hexana fraction of black garlic & 75 & $36.86 \pm 37.16$ & $1.11 \pm 0.23$ \\
\hline B & Chloroform fraction of black garlic & 1.5 & $409.81 \pm 40.12$ & Not detected \\
\hline & Ethyl acetate fraction of black garlic & 3.5 & $293.76 \pm 28.61$ & $10.66 \pm 0.58$ \\
\hline & Residu of ethanol fraction of black garlic & 210 & $411.209 \pm 17.75$ & $9.81 \pm 0.43$ \\
\hline & $\begin{array}{l}\text { Water extract of garlic }(100 \mathrm{~g} / 200 \mathrm{~mL} \\
\text { water) }\end{array}$ & $\begin{array}{l}150 \mathrm{ml} \text { extract water } \\
\text { (not evaporated) }\end{array}$ & $165.16 \pm 13.81$ & Not detected \\
\hline$\checkmark$ & $\begin{array}{l}\text { Water extract of black garlic }(100 \mathrm{~g} / 200 \\
\mathrm{mL} \text { water })\end{array}$ & $\begin{array}{l}150 \mathrm{ml} \text { extract water } \\
\text { (not evaporated) }\end{array}$ & $296.32 \pm 30.25$ & Not detected \\
\hline
\end{tabular}

The separation of components in the ethyl acetate fraction of black garlic was carried out using gravity column chromatography. From this separation, one component is obtained indicating high purity. Identification of these components using IR and GCMS. The IR data of the isolated compounds are shown in Figure 1. The functional groups present in the isolated compound can be identified through an IR spectroscopic analysis. The results of the analysis using IR indicate that the compound contains a hydroxyl group, $\mathrm{C}=\mathrm{O}$; and $\mathrm{C}=\mathrm{C}$.

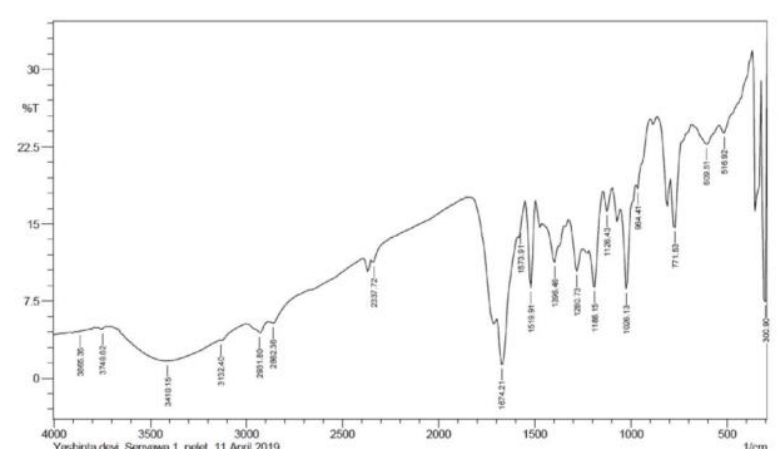

Figure 1. IR Spectrum of the compound isolated from the ethyl acetate fraction of black garlic

GC-MS analysis was used to identify the relative mass $(\mathrm{m} / \mathrm{z})$ and fragmentation of the isolated compound from the ethyl acetate fraction shown in figure 2. Based on the GC-MS spectrum, the isolated compound was still mixed with several other compounds.
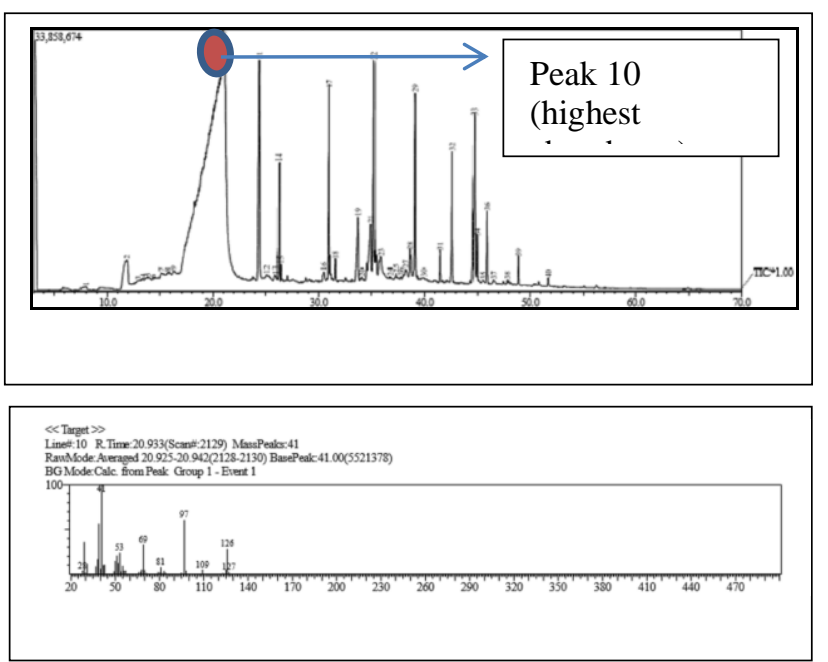

Figure 2. Spektrum GC-MS isolated compound 
Table 2. The antioxidant activity test of each extract and fraction from garlic and black garlic

\begin{tabular}{|l|l|c|}
\hline \multicolumn{2}{|c|}{ Sample } & $\begin{array}{c}\text { Antioxidant activity }\left(\mathrm{IC}_{50}\right. \\
(\mu \mathrm{g} / \mathrm{mL})\end{array}$ \\
\hline \multirow{4}{*}{$\mathrm{A}$} & Total ethanol extract garlic & $938.897 \pm 0.12$ \\
\cline { 2 - 3 } & $n$-Hexane fraction garlic & $713.134 \pm 1.26$ \\
\cline { 2 - 3 } & Chloroform fraction of garlic & $1316.671 \pm 2.12$ \\
\cline { 2 - 3 } & Residu of ethanol fraction of garlic & $345.58 \pm 0.19$ \\
\hline \multirow{4}{*}{$\mathrm{B}$} & Total ethanol extract black garlic & $38.609 \pm 0.11$ \\
\cline { 2 - 3 } & $n$-Hexane fraction of black garlic & $363.69 \pm 1.12$ \\
\cline { 2 - 3 } & Ethyl acetate fraction of black garlic & $287.21 \pm 0.34$ \\
\cline { 2 - 3 } & Residu of ethanol fraction of black garlic & $311.09 \pm 1.07$ \\
\hline \multirow{2}{*}{$\mathrm{C}$} & Water extract of garlic & $913.083 \pm 2.32$ \\
\cline { 2 - 3 } & Water extract of black garlic & $220.71 \pm 1.14$ \\
\hline
\end{tabular}

This is because the spectrum obtained has 40 peaks, but the highest abundance is at the $10^{\text {th }}$ peak with an abundance of $67.89 \%$. After conducting a literature study, the compound in the GC-MS data library, the fragmentation pattern that most closely matches the peak spectrum fragmentation pattern of $10^{\text {th }}$ is the spectrum of 2-furancarboxyldehyde compound or often called 5hydroxymethylfurfural. The compound has the molecular formula $\mathrm{C}_{6} \mathrm{H}_{6} \mathrm{O}_{3}$, molecular weight $\mathrm{m} / \mathrm{z} 126$, and a similarity index of 83 .

The mass spectrum at peak $10^{\text {th }}$ has a molecular weight of $126 \mathrm{~m} / \mathrm{z}$ which is thought to be the peak of molecular ion $[\mathrm{M}+]$. The ion peak shown at $\mathrm{m} / \mathrm{z}$ 125 is the release of the hydrogen molecule. Meanwhile, the peak that appears at $\mathrm{m} / \mathrm{z} 97$ is the termination of the side chain (-CO) attached to carbon atom number 2 followed by a ring change from pentagonal to hexagonal shape. According to According to the Metabolomics Innovation Center, the 5-hydroxymethyl-2furancarboxaldehyde compound or commonly known as 5-hydroxymethylfurfural (5-HMF) can be found in black garlic [16]. This compound is obtained from various carbohydrate compounds. 5-HMF compound is a compound found in many plant species, including in tomatoes, tobacco oil, and others. This compound is used as an index of heating treatment and damage to foods such as tomato paste, honey, and fruit juices. A 5$\mathrm{HMF}$ compound is a furan group, which is a compound containing a furan ring indicated by a pentagonal aromatic ring with one oxygen atom and four carbon atoms formed from amino acids with reducing sugars. These reactions usually require heat and occur during the preparation or manufacture of various types of food or beverages by roasting. This reaction causes changes in color, taste, and nutritional content[17]. 5-HMF was only obtained in the ethyl acetate fraction of black garlic, whereas in garlic it did not produce ethyl acetate fraction. This shows that the fermentation process has changed the carbohydrates or sugars in garlic to 5-HMF.
The antioxidant activity test of each extract and fraction from garlic and black garlic was carried out using the DPPH method. The test results of each extract and fraction are shown in Table 2. The results of this study indicate that the levels of phenolic compounds from the extract and fraction of black garlic are higher than those in white garlic. This is because in the fermentation process there is a hydrolysis reaction to break down phenolics in the form of glucosides. The presence of high phenolic compounds in the extracts and

fractions affects their antioxidant activity. The results of this study indicate that the total ethanol extract of black garlic has the highest antioxidant activity with $\mathrm{IC}_{50}$ $38.609 \pm 0.11 \mu \mathrm{g} / \mathrm{mL}$. Phenolic compounds are very good chemical compounds as oxygen radical scavengers. Phenolic compounds can act as reactive oxygen radical scavenger intermediates without triggering further oxidation reactions so that phenolic compounds are known to have antioxidant and antiradical activity[18].

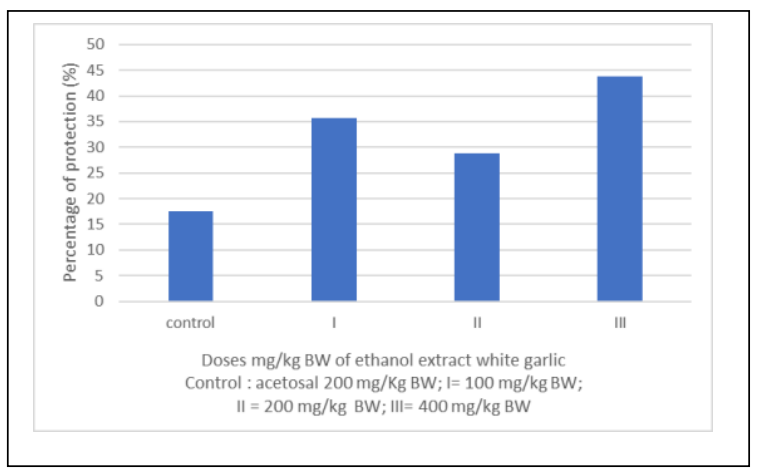

Figure 3. The in vivo analgesic activity test of the ethanol extract of garlic

The in vivo analgesic activity test of the ethanol extract of garlic and black garlic is shown in Figure 3 and 4 . The data shows that the analgesic activity test carried out in vivo shows that the ethanol extract of black garlic has a higher analgesic activity. From these data, it 
can also be seen that the ethanol extracts of garlic and black garlic have higher analgesic activity compared to the positive control group using acetosal. This is by the results of a previous study reported by Dange [19]. The main phytoconstituents such as thioacremonone, allicin, ajoene, and quercetin in garlic can inhibit cyclooxygenase peripherally and act on opioid receptors which centrally lead to analgesics.

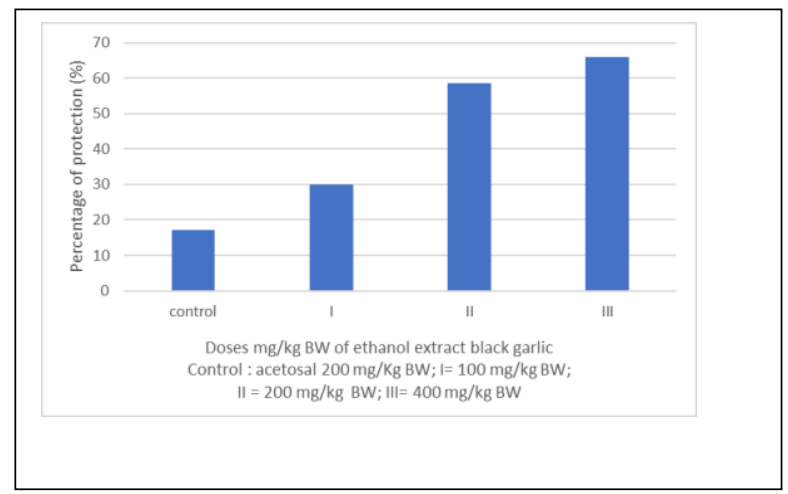

Figure 4. The in vivo analgesic activity test of the ethanol extract of black garlic

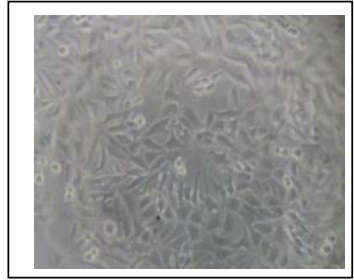

A

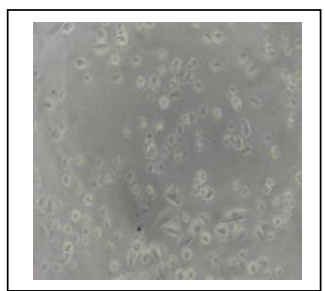

B
Figure 5. The results of observations of T47D breast cancer cell before treatment (A) and breast cancer T47D cell after treatment (B) with 700 $\mu \mathrm{g} / \mathrm{mL}$ chloroform fraction of black garlic

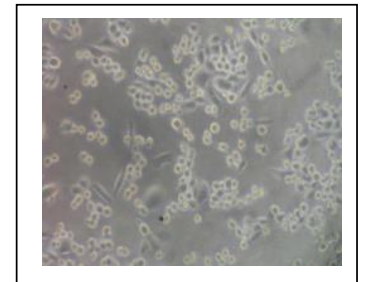

A

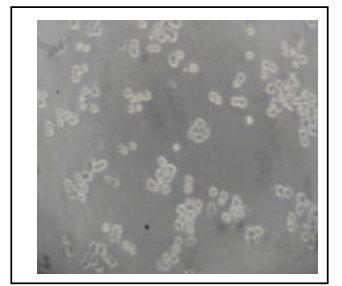

B
Figure 6. The results of observations of Hela S3 cell before treatment (A) and Hela S3 cell after reatment (B) with $300 \mu \mu \mathrm{g} / \mathrm{mL} \quad$ chloroform fraction of black garlic

Anticancer activity tests were carried out in vitro using cancer cells T47D, 4T1; MCF7 / Her2; HeLa; and WiDr. The activities expressed in the $\mathrm{IC}_{50}$ chloroform fraction of black garlic against cancer cells T47D, 4T1; MCF7 / Her2; HeLa; and WiDr are 447.455; 227.562; 200.806; 510.466; and $429.001 \mu \mathrm{g} / \mathrm{mL}$. Whereas other extracts and fractions of garlic and black garlic showed $\mathrm{IC}_{50}$ values greater than $1000 \mu \mathrm{g} / \mathrm{mL}$ which indicated very lower cytotoxic activity. The results of observations of T47D and HeLa cancer cells in treatment with chloroform extract of black garlic are shown in Figure 5 and 6.

\section{CONCLUSION}

The total phenolic and flavonoid levels of garlic and black garlic extracts showed a difference. The total phenolic and flavonoid levels of the ethanol extract of garlic were $71.54 \pm 11.31 \mathrm{mg} \mathrm{GAE} / \mathrm{g}$ sample and 2.32 $\pm 0.22 \mathrm{mg} \mathrm{RE} / \mathrm{g}$ sample, respectively, whereas in the ethanol extract of black garlic it was $306.09 \pm 32.23 \mathrm{mg}$ $\mathrm{GAE} / \mathrm{g}$ sample and $9.25 \pm 0.55 \mathrm{mg} \mathrm{RE} / \mathrm{g}$ sample. The results of the isolation and identification of the ethyl acetate fraction of black garlic showed the presence of 5-hydroxymethylfurfural compounds with a percentage of $67.89 \%$. The antioxidant activity of black garlic extract showed high activity with $\mathrm{IC}_{50} 38.609 \pm 0.11$ $\mu \mathrm{g} / \mathrm{mL}$, while the ethanol extract of garlic showed lower activity. The ethanol extract of garlic and black garlic has higher analgesic activity than acetosal, while its activity against some cancer cells shows low activity.

\section{ACKNOWLEDGMENTS}

This research was funded by a group research grant from the Department of Chemistry Education, Faculty Mathematic and Natural science, Universitas Negeri Yogyakarta in 2019. The author would like to express his gratitude for the funding.

\section{REFERENCES}

[1] Rivlin, R. Historical perspective on the use of garlic J. of Nut. 131 (3S), 2002, pp 951S-954S. DOI: $10.1093 / \mathrm{jn} / 131.3 .951 \mathrm{~S}$.

[2] Nencini C, Menchiari A, Franchi G. G, Micheli L. In vitro Antioxidant Activity of Aged Extracts of some Italian Allium Species, Plant Foods for Human Nut. 66, 2011, pp. 11-16. DOI: https://doi.org/10.1007/s11130-010-0204-2.

[3] Choi IS, Cha HS, Lee YS, Physicochemical and Antioxidant Properties of Black Garlic Molecules, 19,2014,pp.16811-16823.

DOI: https://doi.org/10.3390/molecules191016811

[4] Xiaoming L, Ningyang Q, Zhichang Q, Pengli L. Composition analysis and antioxidant properties of black garlic extract, $J$. of food and drug anal. 25(2), 2017,pp 340-349. DOI: 10.1016/j.jfda.2016.05.011

[5] Park JH, Park YK, Park EJ. Antioxidative and antigenotoxic effects of garlic (Allium sativum L.) prepared by different processing method, Plant Foods for Human Nut. 64, 2009, pp 244-249. DOI: 10.1007/s11130-009-0132-1. 
[6] Gonzales ALC, Al SF, Tunez I, Santamaria A, On the antioxidant, neuroprotective and antiinflammatory properties of S-allyl cysteine: An update, Neurochem. Inter. Xxx, 2015, pp 1-9. DOI: https://doi.org/10.1016/j.neuint.2015.06.011

[7] Park C, Park S, Chung YH, Kim G, Choi YW, Kim BW, Choi YH, Induction of apoptosis by a hexane extract of aged black garlic in the human leukemic U937 cells, Nut. Res. and Prac. 8(2), 2014, pp 132137. DOI: $10.4162 /$ nrp.2014.8.2.132

[8] Yoo JM, Sok DE, Kim MR. Anti-Allergic Action of Aged Black Garlic Extract in RBL-2H3 Cells and Passive Cutaneous Anaphylaxis Reaction in Mice, J Med Food 17, (1), 2014, pp 92-102. DOI: $10.1089 /$ jmf.2013.2927

[9] Kimura S, Tung YC, Pan MH, Weisu N, Lai YJ, Black garlic: A critical review of its production, bioactivity, and application J. of Food and drug Anal. $25 \quad$ (1), 2017, pp 62-70. DOI: 10.1016/j.jfda.2016.11.003 .

[10] Casas LM, Yustyy ML, Hernandes JL. 2017. Changes in the Aromatic Profile, Sugars, and Bioactive Compounds When Purple Garlic Is Transformed into Black Garlic, J. Agric Food Chem 13, 2017, pp 10804-10811. DOI: 10.1021/acs.jafc.7b04423

[11] Hagerman A, Harvey-Mueller I, Makkar AH, Mueller IH, Makar HPS. Quantification of Tannins in Tree Foliage - aLaboratory Manual; FAO/IAEA: Vienna, 2000.

[12] Malencic D, Milan P, Jegor M, 2007 Phenolic Content and Antioxidant Properties of Soybean (Glycine $\max$ (L.) Merr.) Seeds, Molecules , 12(3), 2007, pp 576-81. DOI: 10.3390/12030576.

[13] Atun S, Handayani S, Rakhmawati A, Purnamaningsih NA, Naila BIN, and Lestari A. Study of Potential Phenolic Compounds from Stems of Dendrophthoe Falcata (Loranthaceae) Plant as Antioxidant and Antimicrobial Agents. Orient. J. Chem. 34 (5), 2018, pp 2342-2349. DOI: $10.13005 / \mathrm{ojc} / 340515$

[14] Mishra D, Ghoshi G, Kumar PS, Panda PK, An experimental study of analgesic activity of selective COX-2 inhibitor with conventional NSAIDs, Asian J.of Pharm. and Clin. Res. 4 (1), 2011, pp 78-81.

[15] Atun S, Arianingrum R. Anticancer Activity of Bioactive Compounds from Kaempferia rotunda Rhizome Against Human Breast Cancer, Inter. J. of Pharm. and Phyt. Res. 7(2), 2015, pp 262-269.

[16] WangW, Wang Y, Wang C, Sun Y, Gao M, Effect of maillard reactions on nutrien and antioxidant activity on garlic, Food Sci Technol. 4, 2013, pp $0-11$.
[17] Kim HK, Young WC, Eun NL, Jin KP, Sun GK, Da JP, Bong SK, Young TK, Sik Y. 5Hydroxymethylfurfural from black garlic extract prevents TNF $\alpha$-induced monocytic cell adhesion to HUVECs by suppression of vascular cell adhesion molecule-1 expression, reactive oxygen species generation and NF- $\mathrm{KB}$ activation, Phytother. Res. 25 (7), 2011, pp 965-974, DOI: 10.1002/ptr.3351

[18] Hung CY, Yen GC, Antioxidant activity of phenolic compounds isolated from Mesona procumbens Hemsl, J. of Agric. Food Chem. 50, 2002, pp 2993-2997. DOI: 10.1021/jf011454y

[19] Dangel SV, Mathew J, Datta A, Tilak AV, Jadhav M, Evaluation of the analgesic efficacy of garlic shoots extract in experimental pain models in mice, Int J Basic Clin Pharmacol.5(6), 2016, pp 23932396,DOI:http://dx.doi.org/10.18203/23192003.ijbcp20164094 